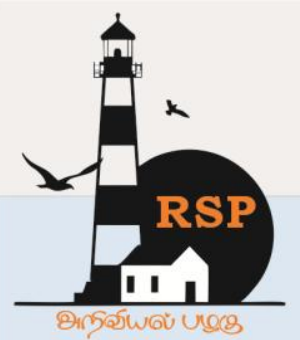

INTERNATIONAL RESEARCH JOURNAL ON

e-ISSN : 2582 - 4376 ADVANCED SCIENCE HUB Open Access

RSP SCIENCE HUB

(The Hub of Research Ideas)

Available online at www.rspsciencehub.com

\title{
Cultivating Grit for Students Career Maturity: An Overview of Christian Education Approach to Combat Covid-19 Pandemic Effect
}

Siani Listio ${ }^{1}$, Hotman Parulian Simanjuntak ${ }^{2}$, Marlon Butarbutar ${ }^{3}$, Vera Setyowati ${ }^{4}$

${ }^{1}$ Lecturer, Dept. of Christian Education, STIPAK Malang, Jl. Janti Barat blok A no 48 Malang, East Java, Indonesia.

${ }^{2}$ Assistant Professor, Internal Quality Assurance, Indonesian Bible Institute, Jl. Trunojoyo no. 12 Batu, East Java, Indonesia.

${ }^{3}$ Chairman, Regional Council of Indonesian Missionary Foundation - Sumbagsel Jl. Buluran/Gereja no.2 Tanjung Enim, South Sumatera, Indonesia.

${ }^{4}$ Headmistress, Mawar Saron Elementary School, Jl. Palem XIII blok B14 no.1E perum taman Cibodas, Banten, Indonesia.

sianilistio584@gmail.com ${ }^{1}$, hotmanp.simanjuntak76@gmail.com ${ }^{2}$, marlonbutarbutar1968@gmail.com ${ }^{3}$, verasetyowati417@gmail.com ${ }^{4}$

\section{Abstract}

Christian educators often struggle to motivate students in pandemic era. There was a big crisis among them to develop the ability to manage strong emotions and respond effectively to stressful situations, which affected to their career maturity. It was necessary to cultivate "perseverance and passion for long-term goals," named grit. The objective of this study was to determine the effectiveness of grit to career maturity. This study was a quantitative research, applied causal design. The research subjects were Christian college students in East Java, 90 in numbers, using random sampling. The analysis was done by using simple linier regression and obtained the coefficient of determination 0.923. It meant that grit influenced students' career maturity by $92.3 \%$, while $7.7 \%$ was influenced by other factors. From the finding, to combat Covid-19 pandemic effect that caused students' career maturity had been decreasing, Christian educators should cultivate grit.

Keywords: Grit, Career Maturity, Christian Education, Pandemic

\section{Introduction}

Christian educators often struggle to motivate students in pandemic era. There was a big crisis among them to develop the ability to manage strong emotions and respond effectively to stressful situations. It was necessary to cultivate "perseverance and passion for long-term goals," which Angela Duckworth defined it as a grit. The objective of this study was to determine the effectiveness of grit to career maturity.
Grit demands hard work to face challenges, sustain effort and interest over the years despite the ongoing failures, difficulties, and setbacks. Duckworth also described grit as a stamina to keep on doing something for years, passing through various challenges, difficulties, failures, even stagnation. Perkins-Gough included grit not only has resistance in the face of failure, but also has a deep commitment that you remain faithful for many years. Duckworth formulated the grit 
associated with the following talents, toughness, and achievement [1].

\subsection{Cultivating Grit}

Grit was one of the characters that a student must have to always remain strong integrity and personal and persevere in working on the duties and responsibilities as a student. Students needed to have a personal control over anything that is within them to avoid focusing on the duties and responsibilities that students are supposed to do in the classroom. Overall it depended on the determination, enthusiasm, and diligence to achieve the goals they were doing [2].

It was stated that grit is two interconnected components that relate to each other, namely: (a) passion was all things sacrificed to achieve a purpose; (b) perseverance was one characteristic of a person to maintain persistence and a spirit in achieving long-term goals. It was performed continuously with full persistence and passion for a goal that will be achieved in a long period of time [3].

Based on the above exposure it could be concluded that the indicator of the grit was having a passion and perseverance that made a single entity interconnected. It could be concluded that grit was the resilience and the spirit to achieve long term goals. Individuals who had persistence would strive to pursue their intended goals by striving and consistent with their choices [4].

To develop grit in a student, it was important to develop a habit or culture within the school about self control, the planting of God's word, and the motivation of a leader [5]. Meanwhile, it was said that "developing grit made the individual to overcome the challenges that arose and improved the state of mind arising and ensure the condition of each individual becomes successful."

There were several ways to cultivate and develop grit in students [6]:

- Find Interest

Interest was essentially an "acceptance of something of a relationship between yourself and something outside." The ability of the student to remain diligent in doing all the tasks and responsibilities well that was by the way of discovery what the student was interested in or the child's interest. Example: If a child was interested in writing, then things were done starting to write.
- Hard Practice

Practice was a set of frameworks, ideas, information tools, language styles, stories, as well as documents regarding knowledge-sharing activities among community members. That means in doing a goal, it was necessary to exercise hard to achieve it for maximum results.

- Teach to respect others

Respecting others (empathy) was the key for students to develop diligence, never give up and grit. With students able to understand and perceive the feelings of others, they will be able to build a longer and deeper relationship. The students will also be able to be sensitive to the problems that people are experiencing around them.

- Teach Self-Respect

Cultivating grit in students was very difficult if the student himself did not perceive valuable and able to achieve success. Every student needs to be able to protect themselves to be firm with himself and need the planting of the cultivation that helps the students develop mentally.

- Reducing Negative Feelings

The process in inflating persistence in a student, often they face other people who easily underestimate the dream and question the dreams made. There were several ways to control negative feelings: "Think positively, cherish the opinions of others, be patient and be forgiving, distract."

- Making a plan

Giving students the opportunity to plan life was important to them. Take time to talk about plans for those in the future. This plan in achieving a predetermined goal was to give direction for every action required and made for the individual.

- Follow the process

Doing every plan was a very good thing, but following every process from each planning was not less important. Following every process of the plan properly would keep the student's motivation also remains good.

- Being an example

Example would be the most convincing method of success in preparing and shaping a good student, moral, spiritual and social attitude. The largest inspiration for student was parents. Being an example for the student in a life, it took a strong and always strong commitment to what was done as a key factor for a child to be resilient, never give up (grit). Therefore, being an example was an 
attitude that requires determination of heart in achieving a purpose.

- Learning to make decisions

Decision making was a result of solving in a problem that must be faced firmly. The decision literally means choice. In a decision that was: (1) a choice on the basis of logic or consideration; (2) There were several alternatives that should be chosen one of the best; and (3) there was a purpose to be achieved and the decision is closer to that goal. Making a decision was a great thing for a student. One component that a student must have was to be a grit that can form a proper and rational decision [7].

- Find out who they are

Recognizing the self is very important to the child before he acted that he could not yet understand himself. By recognizing and understanding the efficacy and objectives that you want to achieve, in this case, if difficulties come then the children know how the power can defeat the weakness in the self.

\subsection{Career Maturity}

Career maturity was an individual's ability to plan and search for the right career possibilities according to their age and level of development, looking for information on career options relevant to him, overcoming developmental tasks in the stages of growth, exploration, improvement, maintenance, and release [8].

The concept of career maturity had several dimensions, namely:

- Career planning

This dimension measured how often individuals looked for a variety of job information and how far they knew about different types of work. How much individual planning was important in this concept. Some of the activities covered by this concept included: study information related to the type of work in demand, talk about planning made with adults (more experienced people), follow courses that can help make career decisions, participate in extracurricular activities or internships/part-time, and participate in training or education related to the type of work in demand. This concept was also related to the knowledge of job conditions, required education levels, job prospects, other approaches to entering the job of interest, and opportunities for career advancement
[9]. Career planning refered to how many individuals know about things to do, not on how well they know about the work he was asked for.

- Career exploration

This dimension could be interpreted as a desire to explore or seek information about career options; how much the individual wants to find information from various sources such as parents, other relatives, friends, teachers, counselors, books, and even movies. Career exploration concept related to how much information an individual can obtain [10].

\section{- Decision Making}

This dimension was based on the ability to use knowledge and make career planning. In this case, the individual was positioned in a situation where others have to make the best career decisions [11]. If individuals know how others should make a career decision, they can also make a good career decision for themselves.

- World of Work Information

This dimension had two basic components: the first related to an individual's knowledge of important developmental tasks, such as when others should explore their interests and abilities, how others learn their work, and why people change work [11]. Secondly, it included knowledge of job desks on certain occupations. It was very important for individuals to know the world of work before making career choice decisions.

- Knowledge of the Preferred Occupational Group This dimension related to the knowledge of job desks of the jobs they are interested in, work equipment, and required physical requirements. It also related to individual abilities in identify people who are on the job they are interested in. The categories of interest they can choose included verbal, numerical, clerical, mechanical, scientific, artistic, promotional, social, and outdoors or field work [12].

\section{Method}

This study was a quantitative research, applied causal design. The research subjects were Christian college students in East Java, 90 in numbers, using random sampling. Data was collected by using a combination questionnaire of grit scale and career maturity, passed validity and 
reliability test. Simple linier regression had been used to calculate correlation and coefficient of determination, by SPSS software program.

\section{Results}

\section{Table.1. Reliability Statistic}

\begin{tabular}{|c|c|}
\hline $\begin{array}{c}\text { Cronbach's } \\
\text { Alpha }\end{array}$ & N of Items \\
\hline .794 & 15 \\
\hline
\end{tabular}

Based on the table 1, Cronbach's Alpha obtained 0.794. It meant that the instrument reliabel.

\section{Table.2. Variables Entered/Removed}

\begin{tabular}{|l|l|l|l|}
\hline Model & \multicolumn{1}{|l|}{$\begin{array}{c}\text { Variables } \\
\text { Entered }\end{array}$} & $\begin{array}{l}\text { Variables } \\
\text { Removed }\end{array}$ & Method \\
\hline 1 & Grit $^{\mathrm{b}}$ & & Enter \\
\hline
\end{tabular}

a. Dependent Variable: Career Maturity

b. All requested variables entered.

From table 2 above, it was known that Grit as variable entered, and career maturity as dependent variable.

\section{Table.3. Model Summary}

\begin{tabular}{|l|c|r|r|r|}
\hline Model & $\mathrm{R}$ & $\begin{array}{c}\mathrm{R} \\
\text { Square }\end{array}$ & $\begin{array}{c}\text { Adjusted } \mathrm{R} \\
\text { Square }\end{array}$ & $\begin{array}{c}\text { Std. Error of } \\
\text { the Estimate }\end{array}$ \\
\hline 1 & $.961^{\mathrm{a}}$ & .923 & .921 & 1.061 \\
\hline
\end{tabular}
a. Predictors: (Constant), Grit
b. Dependent Variable: Career Maturity

In the table above it appeared that coefficient of determination was 0.923. It meant that grit influenced students' career maturity by $92.3 \%$, while $7.7 \%$ was influenced by other factors.

\section{Discussion}

Grit was one of the strong spirits in a person to survive and always persevere despite facing various difficulties and obstacles, must remain patient, persistent and still integrity [13]. It was concerned with performing all duties and responsibilities earnestly for something that is very important and appropriate to be done until the purpose is achieved. Grit is also not about an ambition about myself, but the commitment in itself to keep it through what starts from the beginning until it can eventually be achieved [14]. Grit was not like a sprint runner that ran fast in the beginning but became weary in the end for feeling unwilling. It was portrayed as a stable runner, meaning it does not fast at the beginning or is not slow at the end.

The benefits of perseverance and passion in students were [15]:

- Giving the students the skills and mental persevere under any circumstances in the life that occurred in the college or outside the college environment.

- Encouraging students to be able to take risks so that the child could achieve a dream without having to be afraid to fail.

- Helping for the development of the business compared with talent so that the students could know and understand its basic ability then develop to become a skill in him.

- Giving parents, teachers, coaches, and mentors an opportunity to be an example in order for students to learn facing the difficulties that occur in their lives.

- Making the person beneficial to others in terms of transforming the students' interest into a skill, and a rewarding action for their community.

\section{Conclusions}

Based on the result of the study, it can be concluded that grit, that was be implemented in perseverance and passion for long-term goals, influenced students' career maturity. It is recommended to cultivate grit to combat Covid-19 pandemic effect that caused students' career maturity had been decreasing during the pandemic.

\section{References}

[1] Duckworth, Angela. "Grit: The Power of Passion and Perseverance," New York 
City, USA: Penguin Random House, (2017).

[2] Crede, Marcus (2018). What Shall We Do About Grit? A Critical Review of What We Know and What We Don't Know. Educational Researcher, 47(9), 606-611.

[3] Duckworth, A.L. (2017). Grit-Why Passion and Resilliance are the Secrets to Success. London, UK: Vermillion.

[4] Hofer, M. (2010). Adolescents' Development of Individual Interests: A Product of Multiple Goal Regulation? Educational Psychologist, 45, 149-166.

[5] Ariawan, Sandy. (2019). Countering Zeitgeist of Self-Centered through Role Playing Methods among Junior High School Students. International Journal of Education and Curriculum Application, 2(3), 44-49. https://doi.org/10.31764/ijeca.v2i3.2143

[6] Harms, P.D. (2017). Leadership and Stress: A Meta Analytic Review. The Leadership Quarterly, 28(1), 178-194.

[7] Ariawan, S, Kristyana, N. Nurprasetyaningsih, Rusmi. (2020). Virtual Discussion for Improving Motivation: A Christian Education Strategy against Covid-19 Pandemic Effect. International Research Journal on Advanced Science Hub, 2(7), 1-5.

[8] Watson, Mark B. (2014). Career Maturity Assessment on an International Context. International Handbook of Career Guidance, 8(4), 511-523.

[9] Ariawan, Sandy. (2020). Building Critical Thinking in Covid-19 Pandemic Era: Impossible or I am Possible? International Research Journal on Advanced Science Hub, 2(6), 127-130.

[10] Levinson, Edward M. (2011). Six Approaches to Assessment of Career Maturity. Journal of Counseling \& Development, 76(4), 201-217/

[11] Ariawan, S (2018). The Effectiveness of Cooperative Learning Method (Student Team Achievement Divisions) in Christian Education. International Journal of
Education and Curriculum Application, 1(3), 45-50.

https://doi.org/10.31764/ijeca.v1i3.2128

[12] Ozlem, Ulas-Kilic. (2019). The Effects of Career Intervension on University Students' Level of Career DecisionMaking Self-Efficacy: A Meta-Analytic Review. Australian Journal of Career Development, 28(3), 223-233.

[13] Ariawan, Sandy. "Kreativitas Mengajar dan Implementasi Konsep Pastor-Teacher," SulSel: CV. Mitra Ilmu, (2020) http://doi.org/10.31237/osf.io/xe95j

[14] Duckworth, A. (2007). Grit: Perseverance and Passion for Long-Term Goals. Journal of Personality and Social Psychology, 92(6), 87-101.

[15] Demetrio. E. (2017). The Impact of Perseverance and Passion for Long Term Goals (Grit) on Educational Achievements of Migrant Children: Evidence from Tatarstan, Russia, 23(1), 19-27. 